\title{
The Crime of Attacking Private Life in the System of Combating Saudi Informatics Crimes
}

\author{
Khadijah Abdel Hamid Mustafa Al-Qteishat ${ }^{1}$ \\ ${ }^{1}$ Assistant Professor at the Laws Department, Faculty of Business Administration, Princess Nourah Bent Abdel \\ Rahman University \\ Correspondence: Khadijah Abdel Hamid Mustafa Al-Qteishat.
}

Received: November 27, 2017

doi:10.5539/ass.v14n4p51

\author{
Accepted: December 19, 2018 \\ Online Published: March 20, 2018 \\ URL: https://doi.org/10.5539/ass.v14n4p51
}

\begin{abstract}
The Internet has become the scene of many crimes that are completely different from traditional crimes, including crimes against individuals' privacy and privacy, by accessing personal information and data that they maintain using the electronic means and media of the network, ranging from defamation to extortion, Theft and destruction of information, and may even be used to impersonate persons and commit crimes in their name, and so on. Private life is one of the most important concepts that fall within the scope of human rights enshrined in all international covenants and covenants, which are committed to protecting national laws and legislations in all countries. However, technological changes have posed many challenges to the criminal protection of private life in the Internet environment.

This research aims to identify the criminal protection of private life through the Internet in Western and Arabic laws, as a basis for research into the crime of attacking private life in the system of combating Saudi informatics crimes.
\end{abstract}

Keywords: private life, criminal protection, Saudi Regulation

\section{Introduction}

The crime of assaulting the private life on the electronic environment is deemed of the most important crimes which were alerted by the countries that realized the risk of the same on the security and stability of both the individual and community for which they rushed to issue legislations that may secure all the legal protection forms for the private life at the environment of the internet. However, infringing the private life via the internet goes beyond the traditional issues whether regarding the concept of the right of privacy of the individual and its nature and/or the nature of the violations to which he shall be exposed, the means used and the impacts of the said violations. Actually, the studies concerned with the protection of the private life via the internet are still few in spite of the escalating expansion witnessed by the internet services and the super capability of the same to attract millions of individuals daily including, in particular, the chatting sites and the social media in which the individuals tend to save personal information which they may not wish to be accessed by all or that having the others accessed the same may cause their utilization in a wrong way involving assaulting the private life of their owners.

Actually, the current research aims at approaching the crime of attacking the private life in the Saudi Regulation based on highlighting the criminal protection of the private life against the internet crimes as applicable by the comparative laws by adopting the analytical descriptive method being the most suitable for approaching the subject matter and attaining the goals of the research.

\section{The Criminal Protection of the Private Life on the Internet as Applicable by the Western and Arab Laws}

The technological development led to having increased means and methods for threatening the private life and assaulting it as well as infringing its privacy illegally within the framework of the newly emanated crimes committed within the scope of the electronic environment. However, the criminal protection of the private life against the internet crimes is based on determining the nature of the private life and the forms of assaulting it in the internet environment (Othman, 2007, p. 13). 


\subsection{Definition of Private Life on the Internet}

The right of privacy is one of the fore granted rights established for the human being which several aspects are mostly difficult to be determined other than the difficult differentiation clearly between the matters that fall within the private life of the human being and that stands to be of his public life (Hejazi, 2009, p. 604). Yet, most of the modern laws and legislations provided no specific definition for the private life leaving the same for the jurisprudence and the explanation of the law (Yousef, 1998, p. 58; Bshaten, 2012, p. 70).

As for the jurisprudence, then it laid down several definitions for the private life including: "It is the right related to the family, personal, internal and spiritual life of the person once living behind his closed door (Kayed, 1994, p. 8). Further, it defined the private life as being: "the right in which the individual himself shall determine when, how and to what extent shall the information related to his private affairs be accessible by others (Yousef, 1998, p. 59).

As for the French Jurisprudence, then it defined the private life as being: "The right of person to live his life solely and freely as he wishes to the least interfering of others". In fact, the said definition sustained criticisms as some considered that expanding its interpretation shall result in confusing between the freed and private life (Bshaten, 2012, p. 81).

Further, and for the United States, then a judgment delivered in an American court provided that the right to private life "means the right to isolation without being exposed to the unauthorized publishing". In fact, this was the opinion of the jurist (Alan Weston) when he approached the private life within the framework of the individual's relationship with the community as being: "a temporary discretional withdrawal of the individual from the community to a state of isolation or being restricted to a small group in which he shall be peaceful or even at the heart of larger groups but in a state in which his personality shall not be interfered and in which he shall not be obligated to reserve his matters". Further, Weston defined the private life as being: "the need of the individuals, groups and bodies for which they may decide by themselves the extent to which their information transmitted to others would be accessible". Then, he analyzed the said concept to four topics, namely: the privacy, the affinity, the anonymity and the reservation, i.e. he gave the said right a content and counting (Bin Said, 2015, p. 12, 14).

In fact, and in spite of the difficulty to determine the elements of the right in the private life, yet the most important elements include the emotional life, the matrimonial life, the family life, the health condition, the medical care, the phone and private conversations, the financial liability, the political opinions, the religious beliefs, the origin of the person, his place of residence, the sanctity of his house, the privacy of his communications, name, photo and the sanctity of his body as well as his career and the way he spends his leisure times (Al-Ghaferi, 2009, p. 111). In fact, the same was included in the definition made by the International Commission for the right of private life adopted by the Consultative Society of the European Council in articles $(2,3)$ of the Recommendation No. (428) dated January $23^{\text {rd }}, 1970$ (Bshaten, 2012, p. 81).

On the other hand, the American Law Institute defined the private life in terms of encroaching it as being: "Every person who seriously and illegally infringes the right of another person to keep his matters and affairs away from the knowledge of others and that his picture shall not be exposed to the public shall stand liable as towards the person assaulted" (Bshaten, 2012, p. 80). In fact, this definition is deemed the best one adopted by the jurisprudence for the concept of the private life.

However, the private life on the environment of the internet has been defined as being: "the right of the individuals, groups or entities to decide for themselves when and how or to what extent that the information related to them may be accessed by others (Bin Said, 2015, p. 123).

Further, another definition for the private life on the environment of the internet declared the same as being: "the right of the individual to control the process of gathering personal information concerning him and its automatic processing, saving, distribution and using in making the decision related to him or being of an impact on him" (Al-Ustaz, 2013, p. 433).

In fact, fearing from jeopardizing the sanctity of the private life and the personal freedoms shall be at most towards the state and its bodies since the easy transfer and exchange of data between computers may result in an impact on drawing the general policy of the state if the said information shall be monopolized which matter shall result in causing the actual power in the political regime to be with the party that controls the said information through the expert and technicians of the authority during supervising the information (Al-Shawabkeh, 2011, p. 68).

Hence, article (8) of the European Agreement on the Human Rights and basic Freedoms provided that: "every 
person shall have the right of respect of his private life and family life as well as his house and communications for which the public authority may not hinder practicing the said right except based upon the law and as necessary in a democratic community to the interest of the national security and the safety of the public or the economic prosperity of the country to ban the insurrection or crime or otherwise to protect the health, morals or the rights of others and their freedoms" (ECHR, 1950).

\subsection{The Protection of the Private Life on the Internet as Applicable by the Western and Arab Laws}

The recognition of the risk of the computer on the sanctity of the private life started at the western countries since more than three decades for which several laws where issued aiming in one respect of them at protecting the private life against what was so-called "the risks of the automatic processing of the nominal data" (Al-Akoum, 2000, p. 16).

Further, France issued a law on the digital processing and freedom systems in January, 1978 which law obligates all those in charge of the Internet sites, and when dealing with personal data, to notify the information and freedoms national committee since publishing such information on the internet sites shall cause the same to be exposed to violation and the occurrence of illegal acts on them, e.g. the unauthorized pick up, forging, stealing and manipulation. Hence, the committee provides for notifying the persons regarding the risks of posting their personal data on the sites and vests the right upon them to object against the data published about them while they shall have the right of accessibility, correction, objection and deletion of data for legal reasons. However, the information and freedoms national committee laid down guidelines whereby a simplified notification shall be sufficient for the committee if the matter shall be concerned with data that are not risky. On the other hand, and if the matter shall be concerned with data having an extent of sensitivity (e.g. those related to the customs, political, philosophic and religious opinions or those related to the union memberships or the morals of the person), then an explicit approval should be obtained from the concerned person as stated in article (31) which was included in article (226-19) of the Penal Code. For example, and according to the said law, a person was convicted for having posted a picture showing his girlfriend naked on the Internet. In fact, the French Penal Code secured the protection for the private life by the articles $(226 / 1,2,8)$ as the first article is concerned by criminalizing capturing, recording or transferring the conversation issued privately or confidently without the consent of the victim in addition to having criminalized the capturing, recording or transferring the picture of a person from one private place with his/her consent. Further, the second article is concerned with the crime of saving, disclosing or using a recording or a document that was obtained by any of the aforementioned acts. In addition, article (226/8) provided for criminalizing the editorial works made on the voice or photo of a person without obtaining his/her consent. However, the French legislator did not amend the wording of the articles as set forth in the old Penal Code related to the protection of life whether regarding the first crime, i.e. the crime of capturing, recording or transfer of conversation made privately and confidentially without the approval of the victim as provided for in the article (226/1) (Rasaa, 2012, pp. 142-143).

As for USA, then it issued general principles for all the participants in the information field in June, 1995 which included matter related to protecting the personal information of all the participants in the information field including that is related only to the users of the personal information and others of the individuals who provide personal information related to them (Fikri, 2006, p. 258).

In fact, the said principles obligate the users of the information to assess the extent of their impact on the privacy to determine if personal information were captured, disclosed or used in addition to obtaining or maintaining information in a reasonable manner that support the commercial or targeted activities. Further, they obligate the users of the information who gather personal information directly related to the individual to provide sufficient and suitable information to justify their gathering the information stating at the objective or the target of the gathering in addition to stating at the steps and measures that shall be adopted to protect their confidentiality, safety and accuracy in addition to the result of providing and barring the information. In fact, the said principals stressed on the principal of protection whereby they obligated the users of the information to use the suitable technical and administrative controls to protect the confidentiality and the safety of the personal information (Rasaa, 2012, p. 144).

In addition, several of the western countries issued laws that include the protection of the private life against the risks of the information technology, e.g. Austria, Belgium, Germany and Britain.

On the Arab side, and to date there are no regulations or laws specially concerned with the private life and its criminal protection particularly regarding the protection of the privacy and the personal data at the electronic environment of the Internet. Yet, most of the Arab countries rushed to issuing laws for fighting the information or electronic crimes, e.g. the anti-information crimes system issued by the Kingdom of Saudi Arabia as well as the 
Anti-Information Crimes Laws applicable in Syria, Sudan, Qatar, Bahrain, UAE, Yemen and other countries (Al-Ustaz, 2013, p. 439).

As for protecting the private life on the electronic environment of the Internet according to the Egyptian Law, then the same is still governed by the Egyptian Penal Code that stands to be the first Arab law that provides for protecting the private life. Hence, article (309) et. And article (309) et. (A) provide for the protection of the sanctity of the private life in terms of prohibiting the illegal recording of the voice and image in other than the legally authorized cases while it also criminalizes the act of disclosing the said secrets and reveling the same in any way or otherwise to help in doing such acts or threatening to do so. Further, article (310) criminalizes disclosing the secret learnt by the professional or craftsmen though they shall keep such secrets (Hejazi, 2009, pp. 664-665).

In fact, the Egyptian Press Law also cared about the protection of the private life as articles $(21,22)$ of it provide for criminalizing the acts stated upon in the previous article of the Penal Code together with stressing that the protection of the private life of individuals in general is provided for in articles (309), et. and (309) et. (A).

In UAE, the Law No. (5), 2012 on Anti-Information Technology Crimes was issued while articles $(8,9)$ provide for the criminal protection for the sanctity of the private life and the information exchanged publicly on the internet or via any of the IT media.

As in Sudan, the Information Technology Law, and in the second chapter thereof, it provides on penalties by sentencing to jail and a fine against the crimes tapping, capturing or blocking the messages via the internet or computers and the like or to capture or block the same without having a permit to that effect from the attorney general department, the concerned party or the party being the holder of the information.

As for Syria, then the Law No. (17) on Regulating the Communication on the Internet and Anti-Information Crime, 2012 was issued which is of the laws that provide for a definition for the privacy in article (1) thereof as being: "the right of the individual to enjoy a protection for his personal secrets, the personal issued, the family matters, the communications and reputation as well as the sanctity of his house and private property not to be penetrated or reviled without his consent". As for the protection of the private life, then article (23) of the Syrian Law provides for the punishment by sentencing to jail and paying a fail for he who shall publish information on the internet violating the privacy of any person without his consent even if such information shall be true. In fact, the criminalization and the scope of protection is limited to publishing on the internet being one of the media provided for in article (32) of the Syrian Penal Code. In addition, articles $(9,10,15,18)$ of the Syrian Law stated upon the crimes of violating the privacy, e.g. the crime of disclosing data and information, the crime of changing the content, the crime of the illegal accessibility to information system and the crime of blocking the information.

In fact, the researcher points out that the Arab laws and legislations provided for considering assaulting the private life on the environment of the internet as being a crime which committer shall be punished by criminal and civil penalties. Further, it allowed mixing the two penalties but left the issue of assessing and determining the suitable penalty within the discretion of the judge which matter may be elaborated by approaching the crime of assaulting the private life on the internet on view of the matters established by the Saudi Information Combating System.

\section{The Crime of Assaulting the Private Life on the Internet According to the Saudi Regulation}

The Saudi Regulation approaches the crimes on the Internet under a comprehensive frame expressed by the term "the Illegal Accessibility", i.e. the illegal accessibility defined by article (1/7) of the Saudi Regulation as being: "the accessing of a person deliberately to a computer, a website, an information system or computers network being unauthorized to do so. Further, the same has been considered of the information crimes as defined by article (1/8) of the system as being: any act committed involving using a computer or the internet against the provision of this system".

Further, article (3) of the system criminalized tapping the matters sent via the internet or any computer without a true regular cause or otherwise capturing or blocking the same or defaming the others or harming them via the several information technology media (the Saudi Regulation on Anti-Information Crimes).

In fact, article (6/1) of the Anti-Information Crimes Regulation provided for criminalizing the production of the matter that may encroach the public order, the religious values or the public morals or otherwise the sanctity of the private life, the preparing, sending or saving the same via the Internet or any computer" which should be punished by the penalties provided for against the committer.

Actually, and as the researcher believes, the Saudi Regulation did not provide specific forms for the crime of 
assaulting the private life in the environment of the internet while it did characterize the said crime with a general description listing each act that jeopardizes the private life of the individuals or violating their privacy on the internet. Hence, the illegal accessing to the computers of the individuals, their websites, their databases and personal information as well as tapping them, manipulating their data and information, producing matters encroaching them as well as their defamation and other behaviors that infringe the privacy of others or otherwise lead to the distorting, deformation or damaging of the same are all included within the scope of the crime of assaulting the private life considered by the Saudi Regulator as being of the crimes that encroach the public order.

\subsection{Elements of the Crime of Assaulting the Private Life in the Saudi Regulation}

The crime of assaulting the private life in the Saudi Regulation is based on two elements: a material element and an artificial element.

\subsubsection{The Material Element}

Out of the generality of the description used by the Saudi Regulator (encroaching the sanctity of the private life), then the material behaviors by which the said crime may be effected may not be thoroughly and steadily determined but the Saudi Regulator pointed out that the material element in this crime maybe: producing, preparing, publishing or saving a matter that stands to be encroaching the sanctity of the private life. Actually, and as expressed by article (6/1) of the Saudi Regulation, then three material forms may be denoted for the said crime represented as follows:

1- The production of data: which may encroach the sanctity of the private life like the production pictures, drawings, videos or all the activities that are capable of being produced.

2- The behavior based on preparation and publishing: the same includes all that is effected by posting on the internet which may include other several aspects like insulting, contending, defamation or impersonating or otherwise disclosing the secrets and personal data.

3- The material behavior based on messages: the same may be represented by the threatening messages that may be sent via E-mail, social media, mobile phone or the like being a means that may enable the committer to hide himself through the same which shall facilitate achieving his act with no risks.

Actually, the researchers believe the expression of encroaching the private life used by the Saudi Regulation refers to some forms of assaulting the private life on the internet but not all for which the Saudi Regulator caused all the electronic crimes to be included within the scope of the illegal accessing as the crime of assaulting the private life do mostly result in disclosing the negatives of the targeted person and divulging his secrets as well as the personal information that may be obtained illegally after accessing his computer or by fabricating news about him and the like.

Further, the researcher believes that the Saudi Regulation listed the crime of assaulting the private life within several crimes including encroaching the public order, the religious values and the public morals causing them all to be included in one provision which matter may be attributed to that the said crimes fall within a coherent moral frame being integrated in addition to being concerned with the Islamic Sharia that criminalizes encroaching such entities protected by Sharia and in particular protecting the honor, dignity, reputation and privacy of the human being. Nevertheless, the researcher believes that each of the said crimes should have been listed separately out of the various privacy of each of them.

\subsubsection{The Artificial Element}

The crime does not represent a pure material part based on the act and its subsequences but it is over that stands to be a psychological entity as the material elements of the crime do not solely create a responsibility which matter has been provided for by article (6-1) of the Saudi Information Crimes Combating Regulation as we find it to have pointed out the deliberate character of the crime by having started by the term (production) and that the productivity here is represented by a human element that guided his act to produce all that may encroach the sanctity of the private life.

Actually, the researcher finds that the Saudi Regulator caused the artificial element of the crime of assaulting and encroaching the private life to be conditional upon the discretion of the committer towards committing the act and achieving the result at the same time in addition to the term (preparation) which denotes the achievement of (the prior discretion) for the operation of sending or saving what has been produced and posting the same on the internet for which the sixth article provided for the necessity of the availability of the artificial element represented by the criminal deliberation based on knowledge and discretion. 


\subsection{The Penalty of the Crime of Assaulting the Private Life on the Internet According to the Saudi Regulation}

The Saudi Regulation provided for the two types of penalties for the crimes of assaulting the private life, namely: principal penalties and supplementary penalties.

\subsubsection{The Principal Penalty}

Article (6) of the Saudi Regulation provided for the principal penalty for the crime of encroaching the sanctity of the private life, i.e. "sentencing to jail for a term that shall not exceed five years and paying a fine that shall not exceed three million Riyals". However, article (8) of the same regulation provided that the penalty of sentencing to jail or the payment of the fine shall not be less than half of its maximum limit if the crime shall be committed by any of the following: (1) having the committer committed the crime through a syndicate, (2) occupying a public position and having the crime been related to the said position or committing the crime utilizing his authorities or power, or (3) having local or foreign orders issued previously to the effect of convicting the committer in similar crimes".

In fact, the researcher finds that the provision for this penalty is obviously related to the state of the severe conditions while article (9) provided for the penalty related to instigating or contributing the committing of the crime of assaulting the private life by not more than the maximum limit set for the penalty established for the crime while he shall be punished by not more than half of the higher limit of the penalty set for it if the principal crime shall not occur".

As for the penalty in case of proceeding with the act, then the same has been provided by article (10) of the Regulation by being "either up to not more than half of the maximum limit of the penalty established-i.e. the penalty by sentencing to jail for a term that shall not exceed two years and a half or the payment of a financial fine that shall not exceed one million and a half Saudi Riyal.

\subsubsection{The Supplementary Penalties}

Article (13) of the Saudi Regulation provided for matters denoting determining the supplementary penalty through the provision that stats that "without prejudice to the rights of those of good faith, it may be ordered to confiscate the tools, the programs or the media used for committing any of the crimes provided for in this regulation or to confiscate the funds generated out of the same. Further, it may be ordered to close out the website or the place of delivery of the service definitely or temporarily whenever the same shall be the resource for committing any of the said crimes and that the crime shall have been committed under the knowledge of its proprietor".

Actually, the supplementary penalty is listed under clear frameworks as follows: (1) confiscating the tools, programs or media used in committing the crime; (2) confiscating the funds generated by the media used in the crime; (3) the definite or temporary closing out of the website or the place of delivery of the service in case of proving the same to be a resource for the occurrence of the crime.

Hence, the provision of the article denotes three essential points the first of which is the condition to observe the good faith of those having it while committing the crime and not to jeopardize their rights provided by the Sharia and the regulation while the second is that the said supplementary penalties are those falling under (the possible) penalties regarding the discretion of the court for which the court may order the said penalties or not as it shall deem suitable by its discretional authorities while they are not principal fixed penalties at all. As for the third point then the same is represented in that ordering the penalty of confiscation and closing out of the sight or the place is conditional by two matters to the effect that the said penalties shall be effected to the things proved to have been an element contributing the happening of the crime or resulting from the same and having been obtained by the committer and in case of being possessed by a person other than the committer, the said penalties shall be imposed in case the crime shall have been committed under the knowledge of the proprietor.

\section{The Conclusions}

Accordingly, there is no specific definition or concept adopted by the legislation for the private life or the crime of assaulting the private life as the same was left for the jurisprudence and that the crime of assaulting the private life on the internet have become one of the most important and risky threats sustained and may be incurred by all the individuals using the internet.

Further, it has been shown that the western countries recognized the said types of crimes effected in the cyber environment of the internet since decades for which they hastened to draft laws and bylaws specially dedicated to protecting the private life on the internet which matter has been also effected by most of the Arab countries since few years by issuing laws to combat the information crimes. 
The researcher concluded also that the Saudi Regulation provided for protecting the private life under a general framework titled "encroaching the sanctity of the private life" and has stated upon the elements of the said crime in addition to having provided for the penalties to be imposed on the committer and the contributor as well as in case of proceeding with committing the act.

In fact, the researcher recommends the necessity to regulate the criminal protection for the private life and the crimes of assaulting it in the environment of the internet in the Saudi Regulation as well as the other Arab laws in a way that shall observe the privacy of this crime in addition to demonstrating their force and elements as well as seeking to issuing guiding principles for all of the internet users aiming at educating them and controlling their manners during their working in the electronic environment in addition to stressing on the sanctity of the private life and showing the penalties provided for to each who may think of assaulting the privacy of others or infringing their private life in the way applied by most of the developed countries.

\section{References}

Al-Aacum, W. (2000). The Concept and Phenomenon of the Information Criminology. Works of the Conference on Law, Computer and Internet - University of United Arab Emirates, Abu Dhabi.

Al-Ustaz, S. A. (2013). Violating the Sanctity of the Private Life on the Internet-Comparative Study. University of Damascus Economic and Legal Science Journal, 29(3), 421-455. Retrieved from https://www.damascusuniversity.edu.sy/mag/law/images/stories/3-2013/a/421-455.pdf

Bshaten, S. (2012). The Legal Protection of the Private Life- a Comparative Study (PhD Thesis). Mawloud Mouamri University, Teze Wazzu Algeria. Retrieved from https://bu.umc.edu.dz/theses/droit/AAGU3643.pdf

Fikri, A. A. (2006). The Crimes of the Information Systems (PhD Thesis). University of Mansoura, Egypt.

Hijazi, A. F. B. (2009). Anti-Computer and Internet Crimes in the Typical Arab Law. Dar Al-Nahda Al-Arabia, Cairo.

Kaid, O. A. (1994). The Criminal Protection of the Private Life and the Information Banks. Dar Al-Nahda Al-Arabia, Cairo.

Othman, T. (2007). Criminal Protection of Private Life on the Intrenet-A Comparative Study (MA Thesis). University of Mohammad Khaidar-Biskra, Algeria. Retrieved from http://thesis.univ-biskra.dz/1867/

Rassa, F. (2012). The Criminal Protection of the Information on the Internet (MA Thesis). University of Abu Baker Belqaid, Talmasan, Algeria. Retrieved from http://www.dspace.univ-tlemcen.dz/bitstream/112/2818/rasaa3.pdf

Said, S. B. (2015). Protecting the Right of the Sanctity of the Private Life in the Technology Era - Information and Communication ( $\mathrm{PhD}$ Thesis). University of Haj Lkhader-Patna, Algeria. Retrieved from $\mathrm{http}$ ://theses.univ-batna.dz/index.php?option=com_documan\&task=doc_details\&gid=4488\&Itemid=3

European Agreement on the Human Rights and his Basic Freedoms, 1950.

Information Crimes Law, 2007 Sudan.

Law No. (5), 2012 On Anti-Information Technology Crimes - United Arab Emirates.

Law No. (17) on Regulating the Communication on the Internet and Anti-Information Crime, 2012-Syria.

The Royal Decree (V/17) On the Anti-Information Crimes Law, 1428 Hijra-Kingdom of Saudi Arabia.

\section{Copyrights}

Copyright for this article is retained by the author(s), with first publication rights granted to the journal.

This is an open-access article distributed under the terms and conditions of the Creative Commons Attribution license (http://creativecommons.org/licenses/by/4.0/). 